\title{
Emerging Trends in Combinations of Gefitinib and Cytotoxic Agents: New Opportunities
}

\author{
Josep Tabernero Teresa Macarulla \\ Medical Oncology Department, Vall d'Hebron University Hospital, Barcelona, Spain
}

In the last 10 years, many pharmacological and biological approaches have been tested to develop novel targeted agents that are able to selectively inhibit important pathways that control cancer cell proliferation and growth [1]. The blockade of the epidermal growth factor receptor (EGFR) signal transduction pathway has emerged as one of the most successful strategies in the treatment of cancer with a wide preclinical and clinical evaluation [2]. The EGFR is a transmembrane glycoprotein with three different parts: an external ligandbinding domain, a transmembrane domain and an intracellular tyrosine kinase domain with catalytic activity [3]. Once the ligands - mainly TGF- $\alpha$ and EGF - bind to the receptor, a dimerisation process is induced. It results in the formation of either homodimers or heterodimers with other receptors of the HER family, producing autophosphorylation of different tyrosine residues located in the catalytic domain of the receptor, triggering different signalling transduction cascades that lead, at the end, to critical cellular processes such as proliferation, survival, angiogenesis and production of metastasis (fig. $1)$. The EGFR plays a critical role in most of human carcinomas. Enhanced expression of the ligands - mainly TGF- $\alpha-$ and the EGFR itself has been observed in these tumours and has been shown to negatively correlate with prognosis in many tumour types. EGFR overexpression has been observed in cell lines that are resistant to different cytotoxic drugs. For these and other reasons the EGFR signalling pathway has been in the forefront of the development of targeted therapies directed to control tumour growth. Several pharmacological approaches have been developed to block the EGFR itself. However, only two strategies have reached advanced clinical development: monoclonal antibodies directed to the extracellular domain that compete with the natural ligands [4-6], and low-weight molecules with tyrosine kinase inhibition capacity directed to the endodomain of the receptor $[6,7]$. Several tyrosine kinase inhibitors (TKIs) directed to the EGFR are in clinical development (table 1). Among these inhibitors, gefitinib (ZD1839, Iressa ${ }^{\circledR}$ ) is one of the compounds with the largest preclinical and clinical development.

Gefitinib is an oral anilinoquinazoline, a selective and reversible EGFR-TKI that blocks signal transduction pathways implicated in cancer cell proliferation and other processes connected with cancer growth. Early limited preclinical studies - with in vitro and in vivo evaluation - showed high antitumour activity against different tumour types [8-11]. Moreover, this activity was shown not only when this compound was administered as a single agent but also in combination with several cytotoxic drugs and with radiation therapy. These encouraging results led to the development of a vast clinical programme of gefitinib in many tumour types, with special emphasis on patients with non-small cell lung cancer (NSCLC). The initial phase I studies showed gefitinib to have a good safety profile, with clear clinical activity in some tumour types including NSCLC [12]. Two large randomised phase II studies demonstrated that gefitinib was active in patients with advanced NSCLC refractory to, at least, one previous chemotherapy treatment $[13,14]$. The efficacy results of these two studies were consistent, leading to a fast-track approval by the FDA with the indication of treatment for patients with advanced NSCLC refractory to standard chemotherapy treatment. The next step was to demonstrate that gefitinib could improve the efficacy results of first-line treatment when combined to standard chemotherapy schedules. Some preclinical studies favoured this approach although the experiments were limited with only few tumour cell lines evaluated. The initial phase I studies combining standard chemotherapy schedules with gefitinib showed that this approach was feasible. Two well-designed phase III studies evaluated the role of the addition of gefitinib to two different first-line schedules - cisplatin/gemcitabine and carboplatin/paclitaxel. Unfortunately, these two studies failed to demonstrate any advantage with

\begin{tabular}{ll}
\hline KARGER & ( ) 2005 S. Karger GmbH, Freiburg \\
Fax +497614520714 & Accessible online at: \\
$\begin{array}{l}\text { E-mail Information@Karger.de } \\
\text { www.karger.com }\end{array}$ & www.karger.com/onk
\end{tabular}


Table 1. Epidermal growth factor receptor (EGFR) tyrosine kinase inhibitors (TKIs)

\begin{tabular}{|c|c|c|c|c|c|}
\hline Type of inhibition & Agent & $\begin{array}{l}\text { EGFR IC50, } \\
\mu \mathrm{M}\end{array}$ & $\begin{array}{l}\text { HER-2 IC50, } \\
\mu \mathrm{M}\end{array}$ & $\begin{array}{l}\text { Irrever- } \\
\text { sible }\end{array}$ & $\begin{array}{l}\text { Development } \\
\text { stage }\end{array}$ \\
\hline \multirow[t]{3}{*}{ EGFR specific and reversible } & ZD1839 - gefitinib & 0.02 & 3.7 & no & phase II and III \\
\hline & OSI-774 - erlotinib & 0.02 & 3.5 & no & phase II and III \\
\hline & PKI-166 & - & - & no & phase I \\
\hline EGFR specific and irreversible & EKB-569 & 0.038 & 1.2 & yes & phase I and II \\
\hline \multirow[t]{2}{*}{ EGFR/HER-2 reversible } & GW-2016 - lapatinib & 0.011 & 0.009 & no & phase I and II \\
\hline & BMS-599626 & - & - & no & phase I \\
\hline Pan-HER irreversible & CI-1033 & 0.0008 & 0.019 & yes & phase I \\
\hline $\begin{array}{l}\text { EGFR/HER-2 and VEGFR } \\
\text { reversible }\end{array}$ & AEE788 & 0.002 & 0.006 & no & phase I \\
\hline
\end{tabular}

the addition of gefitinib to standard chemotherapy in NSCLC $[15,16]$. Erlotinib (OSI-774, Tarceva $^{\circledR}$ ), the other EGFR-TKI with advanced clinical development in patients with advanced NSCLC, also failed to show any advantage when combined with the same first-line chemotherapy schedules in the same tumour setting $[17,18]$.

These disappointing results of the combination of EGFRTKIs with standard chemotherapy led to several different hypotheses trying to explain this lack of synergistic effect. Firstly, the objection was raised that the preclinical models that had evaluated the effect of this combination were biased as only a few lung tumour cell lines were analyzed $[8,9]$. Indeed, these lung cancer preclinical models may only reflect a molecular subtype of cancer whose prevalence in the NSCLC type at large is unknown and unpredictable. Secondly, the group at MSKCC showed that gefitinib could have a preclinical synergistic effect when combined with chemotherapy provided that gefitinib was administered at high pulse doses [19]. Thirdly, in the last 18 months it has been shown that those NSCLC patients that achieve the best efficacy with gefitinib as a single agent bear some selected mutations in the catalytic domain of the EGFR [20-22]. Therefore, the effect of gefitinib combined with standard chemotherapy could be diluted due to the low proportion of patients having EGFR mutations. And finally, an antagonistic effect between gefitinib and chemotherapy with the sequence administered in these studies could not be excluded [23].

At the same time it was shown that gefitinib as a single agent had no meaningful activity in patients with advanced colorectal cancer (CRC) [24, 25]. However, gefitinib combined with oxaliplatin/5-flurouracil-based chemotherapy - both in the first-line setting and in a most refractory population - showed encouraging results in limited phase I/II studies [26, 27]. Actually, the efficacy results in terms of response rate achieved within these studies were clearly greater than the results obtained with the same oxaliplatin-based schedules in the same population in larger and pivotal phase III studies. In contrast, another phase I study with the combination of gefitinib and oxaliplatin did not show meaningful activity [28]. These interstudy comparisons only allow to generate hypotheses for the

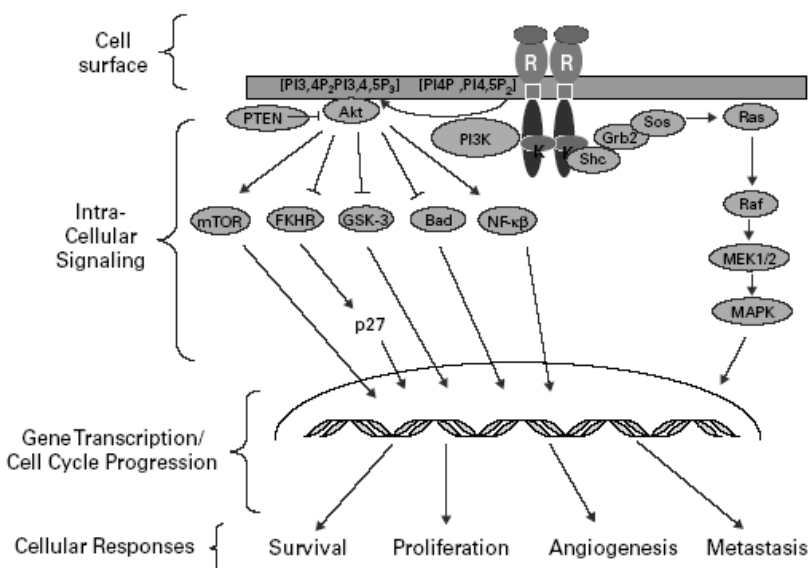

Fig. 1. Epidermal growth factor receptor (EGFR) signal transduction pathways.

design and further development of controlled phase III studies to properly evaluate the role of gefitinib combined with oxaliplatin-based chemotherapy in advanced CRC.

In this issue of the journal, Voigt et al. [29], present the results of a series of preclinical studies evaluating the effect of gefitinib alone or combined with oxaliplatin in different tumour cell lines from CRC, testicular cancer, anaplastic thyroid carcinoma and vulvar carcinoma. Interestingly, the authors showed that gefitinib and oxaliplatin exhibited a synergistic effect in 4 out of 6 different CRC cell lines when these cells were exposed to the combination; in the other 2 cell lines gefitinib did not show any significant interaction with oxaliplatin. In contrast, the combination of gefitinib with oxaliplatin did not exhibit any synergistic effect in the experiments with the other tumour cell lines, including the highly EGFR-expressing vulvar cell line A431. Indeed, in 4 out of 6 non-CRC cell lines this combination exerted a clear antagonistic effect. Moreover, the authors evaluated the cellular effects of gefitinib in the entire tumour cell lines, showing that gefitinib as a single agent only produced cellular changes in the EGFR overexpressing cell line A431, resulting in a marked G1/S accumulation, whereas no significant cell cycle effect could be detected in the cell 
lines expressing low levels of EGFR. The authors concluded that mechanisms of action other than cell cycle perturbation would determine the interaction effect between gefitinib and oxaliplatin in the tumour cells showing synergistic effect. It would be of additional interest to evaluate the interaction effect between gefitinib and oxaliplatin as well as to assess the cellular effects in highly EGFR-overexpressing CRC cell lines, like the DiFi and the Caco- 2 models. Any potential difference between these highly EGFR-expressing and the other CRC cell lines with low EGFR expression levels would help to address the mechanistic effects of this interaction.

$\mathrm{Xu}$ et al. [11] also evaluated the synergistic effects of gefitinib with oxaliplatin. These authors showed that the sequence of exposure has a critical role in the interaction between gefitinib and oxaliplatin, with a synergistic effect when oxaliplatin was followed by gefitinib, while the inverse sequence showed antagonism.
In summary, the present study, as well as other previously published studies, has provided instrumental knowledge to understand the positive interaction between gefitinib and oxaliplatin in CRC cell lines. All these preclinical studies offer a good rationale for the encouraging clinical effect observed in patients with advanced CRC treated with gefitinib combined with oxaliplatin-based chemotherapy in phase I/II studies. The next step would be to design and conduct randomized phase II studies or phase III studies with early stopping rules. All these studies should incorporate transcriptional profiling endpoints, like cDNA arrays and proteomic analysis, to define genomic signatures sensitive to these combinations [30]. The lessons that we have learned from the development of EGFR-TKIs, in addition to the instrumental knowledge that has been generated in the field of cancer cell-signalling, will translate into a more efficient development of these compounds, with a comprehensive interaction between the preclinical and the clinical setting.

\section{References}

1 Hanahan D, Weinberg RA: The hallmarks of cancer. Cell 2000;100:57-70

2 Mendelsohn J: Targeting the epidermal growth factor receptor for cancer therapy. J Clin Oncol 2002; 20:1S-13S.

3 Salomon DS, Brandt R, Ciardiello F, Normanno N: Epidermal growth factor-related peptides and their receptors in human malignancies. Crit Rev Oncol Hematol 1995;19:183-232.

4 Kawamoto T, Sato JD, Le A, Polikoff J, Sato GH, Mendelsohn J: Growth stimulation of A431 cells by EGF: Identification of high affinity receptors for epidermal growth factor by an anti-receptor monoclonal antibody. Proc Natl Acad Sci U S A 1983;80: 1337-1341.

5 Sato JD, Kawamoto T, Le AD, Mendelsohn J, Polikoff J, Sato GH: Biological effect in vitro of monoclonal antibodies to human EGF receptors. Mol Biol Med 1983;1:511-529.

6 Mendelsohn J, Baselga J: Status of epidermal growth factor receptor antagonists in the biology and treatment of cancer. J Clin Oncol 2003;21: 2787-2799.

7 Strawn LM, Shawver LK: Tyrosine kinases in disease: overview of kinase inhibitors as therapeutic agents and current drugs in clinical trials. Expert Opin Investig Drugs 1998;7:553-573.

8 Sirotnak FM, Zakowsky MF, Miller VA, Scher HI, Kris MG: Efficacy of cytotoxic agents against human tumour xenographs is markedly enhanced by coadministration of ZD1839 ('Iressa') an inhibitor of tyrosine kinase. Clin Cancer Res 2000;6: 4885-4892.

9 Ciardiello F, Caputo R, Bianco R, Damiano V, Pomatico G, De Placido S, Bianco AR, Tortora G: Antitumor effect and potentiation of cytotoxics drugs activity in human cancer cells by ZD-1839 (Iressa), an epidermal growth factor receptor selective tyrosine kinase inhibitor. Clin Cancer Res 2000;6:2053-2063.
10 Morelli MP, Cascone T, Troiani T, De Vita F, Orditura M, Laus G, Eckhardt SG, Pepe S, Tortora G, Ciardiello F: Sequence-dependent antiproliferative effect of cytotoxics drugs and epidermal growth factor receptor inhibitors. Ann Oncol 2005;16 Suppl 4:IV61-IV68.

11 Xu JM, Azzariti A, Colucci G, Paradiso A: The effect of gefitinib (Iressa, ZD1839) in combination with oxaliplatin is schedule-dependent in colon cancer cell lines. Cancer Chemother Pharmacol 2003;52:442-448.

12 Baselga J, Rischin D, Ranson M, Calvert H, Raymond E, Kieback DG, Kaye SB, Gianni L, Harris A, Bjork T, Averbuch SD, Feyereislova A, Swaisland H, Rojo F, Albanell J: Phase I safety, pharmacokinetic, and pharmacodynamic trial of ZD1839, a selective oral epidermal growth factor receptor tyrosine kinase inhibitor, in patients with five selected solid tumour types. J Clin Oncol 2002;20: 4292-4302.

13 Kris MG, Natale RB, Herbst RS, Lynch TJ Jr, Prager D, Belani CP, Schiller JH, Kelly K, Spiridonidis H, Sandler A, Albain KS, Cella D, Wolf MK, Averbuch SD, Ochs JJ, Kay AC: Efficacy of gefitinib, an inhibitor of the epidermal growth factor receptor tyrosine kinase, in symptomatic patients with non-small cell lung cancer. A randomized trial. JAMA 2003;290:2149-2158.

14 Fukuoka M, Yano S, Giaccone G, Tamura T, Nakagawa K, Douillard JY, Nishiwaki Y, Vansteenkiste J, Kudoh S, Rischin D, Eek R, Horai T, Noda K, Takata I, Smit E, Averbuch S, Macleod A, Feyereislova A, Dong RP, Baselga J: Multi-institutional randomized phase II trial of gefitinib for previously treated patients with advanced non-small-cell lung cancer. J Clin Oncol 2003;21:2237-2246.

15 Giaccone G, Herbst RS, Manegold C Scagliotti G, Rosell R, Miller V, Natale RB, Schiller JH, Von Pawel J, Pluzanska A, Gatzemeier U, Grous J, Ochs JS, Averbuch SD, Wolf MK, Rennie P, Fandi A, Johnson DH: Gefitinib in combination with gemcitabine and cisplatin in advanced non-small-cell lung cancer: A phase III trial - INTACT 1. J Clin Oncol 2004;22:777-784.
16 Herbst RS, Giaccone G, Schiller JH Natale RB, Miller V, Manegold C, Scagliotti G, Rosell R, Oliff I, Reeves JA, Wolf MK, Krebs AD, Averbuch SD, Ochs JS, Grous J, Fandi A, Johnson DH: Gefitinib in combination with paclitaxel and carboplatin in advanced non-small-cell lung cancer: A phase III trial-INTACT 2. J Clin Oncol 2004;22:785-794.

17 Herbst RS, Prager D, Hermann R, Fehrenbacher L, Johnson BE, Sandler A, Kris MG, Tran HT, Klein P, Li X, Ramies D, Johnson DH, Miller VA: TRIBUTE: A phase III trial of erlotinib hydrochloride (OSI-774) combined with carboplatin and paclitaxel chemotherapy in advanced non-small-cell lung cancer. J Clin Oncol 2005 Jul 25; [Epub ahead of print].

18 Gatzemeier U, Pluzanska A, Szczesna A, Kaukel E, Roubec J, Brennscheidt U, De Rosa F, Mueller B, Von Pawel J, for the TALENT Study: Results of a phase III trial of erlotinib (OSI-774) combined with cisplatin and gemcitabine (GC) chemotherapy in advanced non-small cell lung cancer (NSCLC). Proc Am Soc Clin Oncol 2004;23:A7010.

19 Solit DB, She Y, Lobo J, Kris MG, Scher HI, Rosen N, Sirotnak FM: Pulsatile administration of the epidermal growth factor receptor inhibitor gefitinib is significantly more effective than continuous dosing for sensitizing tumours to paclitaxel. Clin Cancer Res 2005;11:1983-1989.

20 Lynch TJ, Bell DW, Sordella R, Gurubhagavatula S, Okimoto RA, Brannigan BW, Harris PL, Haserlat SM, Supko JG, Haluska FG, Louis DN, Christiani DC, Settleman J, Haber DA: Activating mutations in the epidermal growth factor receptor underlying responsiveness of non-small-cell lung cancer to gefitinib. N Engl J Med 2004;350:2129-2139.

21 Paez JG, Janne PA, Lee JC, Tracy S, Greulich H, Gabriel S, Herman P, Kaye FJ, Lindeman N, Boggon TJ, Naoki K, Sasaki H, Fujii Y, Eck MJ, Sellers WR, Johnson BE, Meyerson M: EGFR mutations in lung cancer: correlation with clinical response to gefitinib therapy. Science 2004;304:1497-1500. 
22 Pao W, Miller V, Zakowski M, Doherty J, Politi K, Sarkaria I, Singh B, Heelan R, Rusch V, Fulton L, Mardis E, Kupfer D, Wilson R, Kris M, Varmus H: EGF receptor gene mutations are common in lung cancers from 'never smokers' and are associated with sensitivity of tumours to gefitinib and erlotinib. Proc Natl Acad Sci USA 2004;101:1330613311.

23 Baselga J: Combining the anti-EGFR agent gefitinib with chemotherapy in non-small-cell lung cancer: How do we go from INTACT to impact? J Clin Oncol 2004;22:759-761.

24 Mackenzie MJ, Hirte HW, Glenwood G, Jean M, Goel R, Major PP, Miller WH Jr, Panasci L, Lorimer IA, Batist G, Matthews S, Douglas L, Seymour L: A phase II trial of ZD1839 (Iressa) $750 \mathrm{mg}$ per day, an oral epidermal growth factor receptortyrosine kinase inhibitor, in patients with metastatic colorectal cancer. Invest New Drugs 2005;23:165170.

25 Rothenberg ML, Lafleur B, Washington MK, Levy DE, Morgan-Meadows SL, Ramanathan RK, Berlin JD, Benson AIB, Coffey RJ: Changes in epidermal growth factor receptor signalling in serum and tumour biopsies obtained from patients with progressive metastatic colorectal cancer (MCRC) treated with gefitinib (ZD1839): An Eastern Cooperative Oncology Group study. Proc Am Soc Clin Oncol 2004;23:A3000.

26 Cho CD, Fisher GA, Halsey J, Jambalos CN, Advani RH, Wakelee H, Lum BL, Sikic BI: A phase II study of gefitinib in combination with FOLFOX-4 (IFOX) in patients with unresectable or metastatic colorectal cancer. Proc Am Soc Clin Oncol 2003;22: A1062.

27 Zampino MG, Lorizzo K, Massacesi C, Rizzi A, Crispino S, Boselli S, Pelosi G, Zorzino L, Fazio N de Braud F: First-line gefitinib combined with simplified FOLFOX-6 in patients with epidermal growth factor receptor-positive advanced colorectal cancer. Proc Am Soc Clin Oncol 2005;24:A3659.

28 Kindler HL, Friberg G, Skoog L, Wade-Oliver K, Vokes EE: Phase I/II trial of gefitinib and oxaliplatin in patients with advanced colorectal cancer. Am J Clin Oncol 2005;28:340-344.

29 Voigt W, Pickhan V, Pfeiffer C, Mueller T, Arnold D, Simon H: Preclinical evaluation of ZD1839 alone or in combination with oxaliplatin in a panel of human tumour cell lines - implications for clinical use. Onkologie 2005;28:482-488.

30 Baselga J, Arteaga CL: Clinical update and emerging trends in epidermal growth factor receptor targeting in cancer. J Clin Oncol 2005;23:2445-2459. 